ISSN: 2146-3042

DOI:

\title{
Bağımsız Denetçi Görüşlerinin Yatırım Kararları Açısından Önemi: Yeni Bir Kesitsel Anomali mi?*
}

\author{
Reşat KARCIOĞLU** \\ Seyhan ÖZTÜRK ${ }^{* * *}$ \\ Cihan YILMAZ****
}

\begin{abstract}
ÖZET
Bă̆ımsız denetim, piyasa etkinliğinin artmasında, özellikle finansal tabloların şeffaflı̆̆ ve şirketlerin mali durumunun menfaat sahiplerince klyaslanabilir bir şekilde anlaşılması açısından olmazsa olmaz bir unsur teşkil etmektedir. Doğru yatırım kararlarının verilmesinde, bağımsız denetçi görüşlerinin ilgili taraflarca doğru biçimde analiz edilmesinin önemli bir faktör olduğu değerlendirilmektedir. Bu çerçevede söz konusu çalışma; bağımsız denetçi görüşlerinin de yer aldı̆̆ bağımsız denetim raporlarının kamuya açılanması sonrasında şirketlerin hisse senedi fiyatlarındaki anormal fiyat hareketlerinin var olup olmadı̆̆ını ve bahsi geçen firmalara özgü anomalilere bir yenisinin daha eklenebilip eklenemeyeceğini araştırmayı amaçlamaktadır. Bu amaç doğrultusunda; olumlu, olumsuz ve görüş bildirilmemiş olan denetim raporlarına sahip şirketlerin 2019 ve 2020 yllına ait denetçi görüşlerinin yer aldiğı altı aylık süreler içerisindeki hisse senedi getirileri hesaplanarak, borsanın tamamın yansıtma özelliğinden hareketle BIST 100 endeksinin getirisi ile karşılaştırılmış ve anormal bir getiri (endeksin üzerinde) elde edilip edilmediği tespit edilmeye çalışılmıştır. Öncül bulgulara göre; Borsa İstanbul (BISST)'un söz konusu dönemler için yarı güçlü formda etkin olmadiğı ve yatırımcıların şirketlerin kamuya açıklanan bağımsız denetim raporlarında yer alan bağımsız denetçi görüşlerinin türüne göre yatırım pozisyonu alarak endeksin üzerinde getiri elde etme olanağına sahip oldukları belirlenmiştir.
\end{abstract}

Anahtar Kelimeler: Bağımsız Denetim, Denetçi Görüşü, Davranışsal Finans, Anomali, Kesitsel Anomali.

JEL Sinıflandırması: M40, M41

\section{The Importance of Independent Auditor's Opinions for Investment Decisions: A New} Cross-Sectional Anomaly?

\section{ABSTRACT}

Independent audit is an indispensable element in increasing market efficiency, especially in terms of the transparency of financial statements and a comparable understanding of the financial situation of the companies. It is considered that the correct analysis of the independent auditor's opinions by the relevant parties is an important factor in making the right investment decisions. In this context, the study in question; After the independent audit reports including the opinions of the independent auditors are disclosed to the public, it aims to investigate whether there are abnormal price movements in the stock prices of the companies and whether a new one can be added to the anomalies specific to the mentioned companies. In accordance with this purpose; By calculating the stock returns of companies with positive, negative and undisclosed audit reports within quarterly periods of 2019 and 2020, it was compared with the return of the BIST 100 index, based on the feature of reflecting the entire stock exchange, and it was tried to determine whether an abnormal return (above the index) was obtained. . According to the preliminary findings; It has been determined that Borsa Istanbul (BIST) is not active in semi-strong form for the said periods and investors have the opportunity to earn an income above the index by taking investment positions according to the type of independent auditor opinions included in the independent audit reports disclosed to the public.

Keywords: Independent Audit, Auditor's Opinion, Behavioral Finance, Anomaly, Cross-Sectional Anomaly.

Jel Classification: M40, M41

* Bu makale, 23-25 Nisan 2021 tarihleri arasında gerçekleștirilen VI. Uluslararası Muhasebe ve Finans Sempozyumunda bildiri olarak sunulmuştur.

Makale Gönderim Tarihi: 28.05.2021, Makale Kabul Tarihi: 22.06.2021, Makale Türü: Nicel Araştırma

** Prof. Dr. Atatürk Üniversitesi, rkarci@atauni.edu.tr, ORCID: 0000-0002-0903-3816.

*** Doç.Dr., Kafkas Üniversitesi, seyhan87ozturk@gmail.com, ORCID: 0000-0003-1458-840X.

**** Öğr. Gör., Ardahan Üniversitesi, cihanyilmaz@ardahan.edu.tr, ORCID: 0000-0001-8620-4888 


\section{GİRiş}

Muhasebe genel olarak parasal işlemleri kaydetmekte, sınıflandırmakta ve en son aşamada raporlar halinde finansal bilgilerden yararlanacak kesimlerin kullanımına sunmaktadır. Raporlamanın sağlıklı ve doğru şekilde yapılması; ortaklar, hissedarlar, yatırımcılar, kredi verenler, halk, devlet, kamu kurumları vb. sayılabilen kesimler için büyük önem arz etmektedir. Raporlamanın hatasız ve doğru şekilde yapılması gereği; çıkar gruplarının güvenilir bilgi ihtiyacı sonuçta bağımsız bir denetimin zorunluluk ve ihtiyaç olduğunu açıkça ortaya koymaktadır. Finansal bilgi kullanan kesimlerin vermiş oldukları stratejik kararlara temel sağlayan finansal tablolarda yer alan verilerin güvenilirlik düzeyinin arttırılmasında, karşılaşılabilecek risklerin en aza indirilmesinde bağımsız denetimin rolü büyüktür. Diğer yandan bağımsız denetçinin bağımsız olması gereği de söz konusu mesleğin önemli bir özelliği olmaktadır. Dünya çapında ya da yerel olarak yaşanan skandallar bu konunun önemini yeterince ortaya koymuş durumdadır. Sonuç olarak denetçilerden beklenen; işletmelerin hazırlayıp sunduğu finansal tablolara güvenilirlik anlamında dayanak oluşturmalarıdır.

Çeşitli teknikler ve yordamlar yoluyla yapılan denetim faaliyeti sonucunda denetçiler finansal tabloları inceleyerek, oluşturdukları görüşlerini yazılı bir rapor olarak kamuoyuna bildirmektedirler. Bu görüşler; "olumlu görüş", "olumsuz görüş", "sınırlı olumlu görüş" ve "görüş bildirmekten kaçınma" şeklinde dört türde olabilmektedir. Denetim raporlarında belirtilen görüşler; diğer kesimlerle birlikte özellikle yatırımcıların kararını etkileyebilmektedir. Çünkü bu raporlar işletmeler hakkında detaylı bilgiler sunmakta ve yatırımcılar da kararlarını ona göre şekillendirmektedirler.

Öte yandan çalışmada denetim görüşleri ile ortak noktada buluşturulan diğer bir konu anomali; genel anlamda teoride yazılanlara paralel olmayan durumları açıklamakta kullanılan bir kavram olarak bilinmektedir. Kısaca genel kabul gören esaslara çok da uymayan, aykırı, normal dışı davranış ya da "çelişki" olarak açıklanabilmektedir. Yaşamın her alanında anomalilerle karşılaşmak olasıdır. Çalışma itibariyle incelenen finansal anlamda anomaliler kendi içinde üç grupta sınıflandırılmaktadır. Bunlar; dönemsel anomaliler, kesitsel anomaliler ve fiyat anomalileri şeklinde sıralanmaktadır.

$\mathrm{Bu}$ çerçevede söz konusu çalışmanın temel amacı; bağımsız denetçi görüşlerinin de yer aldığı bağımsız denetim raporlarının kamuya açıklanması sonrasında şirketlerin hisse senedi fiyatlarında anormal fiyat hareketlerinin var olup olmadığını araştırmaktır.

\section{DENETIM GÖRÜŞLERI}

Denetim faaliyetleri tamamlandıktan sonra bir görüş vermeye hazır hale gelen denetçi; oluşturduğu görüşü doğrultusunda yazılı rapor hazırlayarak karar vericilerin dikkatine sunmaktadır. İşletmelerin sundukları finansal tabloların uzman biri tarafından mesleki değerlendirmeden geçtiğini gösteren tek kanıt denetçilerin hazırladıkları bu "denetim raporu" olmaktadır. Bu noktada söz konusu rapor denetçiler ile finansal tablo bilgilerini kullananlar arasında bir köprü görevi üstlenmektedir (Acar ve Temiz; 2019: 174).

Denetim raporlarının taraflar arasında iletişim ve köprü rolü üstlenmesinden daha ziyade bilgi asimetrisi sorununu azaltması rolü de bulunmaktadır. Denetim faaliyeti süresince 
denetçiler gereksinim duydukları verileri işletmelerden elde ederek; işletme yönetimi tarafından hazırlayıp sunulan finansal tabloların doğruluk, tamlık ve güvenilirlik kıstaslarını incelemek üzere kanıtlar toplamaktadırlar. Topladıkları kanıtlar neticesinde ise; makul bir güvence verilmesi arzu edilen finansal tablolara dair oluşturdukları denetim görüşünü kamuoyuyla paylaşmaktadırlar. $\mathrm{Bu}$ işlemler sayesinde denetçiler tabloların güvenilirliğini arttırmanın yanı sıra finansal tablo kullanıcılarının (özellikle küçük yatırımcıların) bilgi riskini de en aza indirmektedirler (Arens ve diğerleri; 2012).

Denetim raporlarının anlaşılabilir olması özelliği; kullanıcılar tarafından genel kabul görmüş bilgi kaynağı olarak tercih edilmesi hususunda önem teşkil etmektedir. Çünkü denetim raporlarının genel anlamda kabul gören bir bilgi kaynağı olması ekonomik aktörlerin verdikleri kararları yönlendirme ve etkileme gücüne dayanmaktadır. Bu çerçevede denetim raporları ve onların içinde yer alan denetim görüşleri, finansal tablo kullanıcılarının yatırım, borç alma/verme, hisse senedi alım/satım gibi kritik ekonomik kararları üzerinde ciddi bir değişime neden olmaktadır (Bessell ve diğerleri; 2003).

Denetim raporunda yer alan denetçi görüşleri temel olarak dört türde olmaktadır. Bunlar tablodaki şekilde özetlenebilmektedir.

Tablo 1. Denetçi Görüşleri

\begin{tabular}{|c|c|c|}
\hline Önemlilik Düzeyi & Bilgi Kullanıcılarının Kararlarına Etkisi & Denetçi Görüşü \\
\hline Tutarlar Önemsizdir & Kullanıcıların Kararları Etkilenmez & Olumlu \\
\hline $\begin{array}{c}\text { Tutarlar Önemlidir; } \\
\text { Finansal Tablolar Bir } \\
\text { Bütün Olarak Doğru ve } \\
\text { Güvenilirdir }\end{array}$ & $\begin{array}{l}\text { Hata ve Yanlışlıklar Kullanıcıların Kararlarını } \\
\text { Etkilemektedir. Ancak Finansal Raporların } \\
\text { Dürüst Olmasına Gölge Düşmemiştir }\end{array}$ & Sinırlı Olumlu \\
\hline $\begin{array}{c}\text { Tutarlar Yeterince } \\
\text { Önemlidir; Finansal } \\
\text { Tablolar Bir Bütün } \\
\text { Olarak Doğru ve } \\
\text { Güvenilir Değildir }\end{array}$ & $\begin{array}{l}\text { Finansal Tablolara Dayalı Olarak Karar Alan } \\
\text { Kullanıcıların Tümü ya da Çoğunluğunu } \\
\text { Önemli Derecede Etkilemektedir }\end{array}$ & $\begin{array}{c}\text { Görüş Bildirmekten Kaçınma } \\
\text { ya da Olumsuz Görüş }\end{array}$ \\
\hline \multicolumn{2}{|c|}{ Denetci Bağımsız Değildir } & Görüş Bildirmekten Kaçınma \\
\hline
\end{tabular}

Kaynak: Güredin, 2014; Sekizsu ve Ertaş, 2018: 46).

13.01.2011'de yürürlüğe giren 6102 sayılı yeni Türk Ticaret Kanunu (TTK) beraberinde işletmeler için özellikle bağımsız denetim bağlamında; oldukça farklı, önemli ve radikal değişiklikler getirmiştir. Denetim görüşü konusundaki TTKnın getirdiği en önemli farkl1lık "görüş bildirmekten kaçınma" ve "olumsuz görüş verme" konularında olup, aşağıdaki gibi detaylandırılmaktadır (Acar ve Temiz; 2019: 177-178):

- $\quad$ Olumlu Denetim Görüşü: "Denetçi, olumlu görüş verdiği takdirde yazısında, öncelikle 398. madde ve Türkiye Denetim Standartları uyarınca yapılan denetimde, Türkiye Muhasebe Standartları (TMS) ve diğer gereklilikler bakımından herhangi bir aykırılığa rastlanmadığını; denetim sırasında elde edilen bilgilere göre, şirketin veya topluluğun finansal tablolarının doğru olduğunu, malvarlığı ile finansal duruma ve kârlılığa ilişkin resmin gerçeğe uygun bulunduğunu ve tabloların bunu dürüst bir şekilde yansıttığını belirtir."

- $\quad$ Sınırlı Olumlu Görüș: "Finansal tabloların şirketin yetkili kurullarınca düzeltilebilecek aykırılıklar içerdiği ve bu aykırılıkların tablolarda açıklanmış sonuca 
etkilerinin kapsamlı ve büyük olmadığı durumlarda verilir. Sınırlamanın konusu, kapsamı ve düzeltmenin nasıl yapılabileceği sınırlandırılmış olumlu görüş yazısında açıkça gösterilir. Sınırlı olumlu görüş verilen hallerde genel kurul, gerekli önlem ve düzeltmeleri karara bağlar".

- $\quad$ Olumsuz Görüș: "Sınırlı olumlu görüşe yol açan hususların finansal tablolar üzerindeki etkisinin kapsamlı ve büyük olduğu durumlarda verilir".

- Görüs Bildirmekten Kaçınma: "Şirket defterlerinde, denetlemenin yapılmasına ve sonuçlara varılmasına olanak vermeyen ölçüde belirsizliklerin bulunması veya şirket tarafından denetlenecek hususlarda önemli kısıtlamaların yapılması hâlinde denetçi, bunları ispatlayabilecek delillere sahip olmasa bile, gerekçelerini açıklayarak görüş vermekten kaçınabilir".

\section{ANOMALILER}

İlgili alan yazınında etkin piyasalar hipotezi olarak ifade edilen ve Eugene Fama tarafindan 1970 yılında ortaya atılan hipoteze göre; etkin piyasalarda menkul kıymetlere ilişkin bilgiler çok daha az bir maliyetle ve yatırımcılara olabilecek en kısa sürede sağlanmaktadır. Etkin olan piyasalarda; fiyatlar piyasaya ulaşan bilgilere tamamıyla hakim olduğundan; geçmiş dönem verileriyle kar elde etmek bu tür piyasalarda çok mümkün olmamaktadır. Dolayısıyla etkin işleyen piyasalarda spekülatif eylemlerle kâr elde etme imkanı yok olmaktadır (Şahin, 2015: 107). Gelişen piyasalar ve geçen zaman zarfında etkin piyasalar hipotezine karşın; finansal piyasalarda normalden sapma şeklinde gerçekleşen ve anomali olarak adlandırılan durumlar 1970'lerden bugüne en çok tartışılan konulardan biri olmuştur. Bir piyasada anomali varlığı; yatırımcıların normalin üzerinde getiri sağlaması demek olup; söz konusu anomalinin ne zaman ve ne ölçüde gerçekleştiği önem taşımaktadır (Şahin, 2016: 330).

Davranışsal finans, hisse senedi piyasalarının performansını anlamak için bireysel ve sosyal psikoloji alanlarının ilkelerini klasik finans teorisi ile birleştirmektedir. Bu şekilde, finansal piyasalarda ortaya çıkan anomalileri, yatırımcıların davranışları ve karar alma süreçlerine dayandırarak insan davranışının, ekonomistlerin modellemeye çalıştı̆̆ 1 alışılmış yollardan nasıl saptığını analiz etmeye açıklamaya çalışmaktadır. Özetle davranışsal finans, akıl yürütme veya bilişsel hataların yatırımcı kararlarını ve borsada işlem gören menkul kıymet fiyatlarını nasıl etkilediğini anlamaya ve açıklamaya çalışan araştırma alanını temsil etmektedir.

Davranışsal finans literatürü iki ana bölüme ayrılmaktadır (Naveed vd., 2014:68):

- Davranışsal modellerin muhtemelen açıklayabileceği Etkin Piyasa Hipotezi'ndeki anomalilerin keşfedilmesi (De Bondt ve Thaler, 1985),

- Klasik iktisadın rasyonel davranış teorileriyle çelişen bireysel yatırımcı davranışlarının tanımlanması (Odean, 1999).

Anomaliler, davranışsal finansın makro kısmının çalışma alanını oluşturan hisse senedi piyasalarındaki normalden sapmalardır. Eğer ampirik bir sonucu "rasyonelleştirmek" 
zorsa veya paradigma içinde açıklamak için irrasyonel varsayımlar gerekliyse, bu durum “anomali” olarak nitelendirilir (Camerer ve Thaler, 1995: 209).

Anomali, ekonomik, sosyal, finansal anlamda kullanılabilen ve genel kabul gören ilkelerle uyumlu olmayan bir davranış şekli olarak tanımlanmaktadır. Finans literatüründe önemli gelişmelere ön ayak olmuş bir kavram olarak görülmektedir (Güngör, 2003: 109-110).

Finansal piyasalar anomalilerini; dönemsel, kesitsel ve fiyat anomalileri şeklinde üç ayrı grupta toplamak mümkündür. Zaman serilerine ilişkin (dönemsel) anomaliler kapsamında; yılın ayı (Ocak ayı), haftanın günü (Pazartesi günü), hafta sonu, ayın bitişi, yılın bitişi, gün içi, ay içi anomalileri, tatil günleri anomalisi, yaz saati uygulaması anomalisi gibi türler yer almaktadır (Coşkun vd. 2021: 4).

Farklı kaynaklarda temel anomaliler olarak da adlandırılan kesitsel anomaliler, işletmelerin çeşitli finansal oranlarının ilgili piyasa ortalamasına aykırı olduğu durumlarda piyasanın altında veya üstünde getiri elde edilebileceğini açıklamaktadır. Fiyat / kazanç oranı etkisi, piyasa değeri / defter değeri oranı etkisi, firma büyüklüğ̈̈ etkisi, fiyat / satış oranı etkisi, fiyat / nakit akımı etkisi ve kazanç duyuruları etkisi olarak sıralanabilecek kesitsel anomali örnekleri bulunmaktadır (Erdoğan ve Elmas; 2010: 11).

Fiyat anomalileri ise piyasa etkinliğinden sapma durumunu ifade eden, aşırı reaksiyon yada eksik, yetersiz reaksiyon olarak ifade edilmektedir (Barak ve Demireli, 2008: 207). Eksik yada yetersiz reaksiyon verileri; yatırımcıların, hisse senetleri fiyatları ile ilgili bazı veri yada duyumlara 1-12 aylık süreçte, yetersiz ilgi gösterdiğini açıklamaktadır. Aşırı tepkireaksiyon anomalisinde ise hisse senetleri fiyatları, 3 ila 5 yıl gibi uzun süreçte, aynı doğrultudaki veri ve bilgilere tutarlı olarak aşırı ilgi aynı anda aşırı tepki göstermektedir (Barberis ve dig., 1998: 307-308).

\section{LITERATÜR ÇALIŞMALARI}

Alan yazın içerisinde denetçi görüşlerinin hisse senedi fiyatlarına ve yatırımcı kararlarına etkisini konu alan çalışmalardan bazıları aşağıda sıralanmaktadır

Firth (1978), çalışmasında sınırlı olumlu görüş bildiren denetçi görüşünün, hisse senedi fiyatı ve yatırımcı kararları üzerindeki etkisini araştırmayı amaçlamıştır. Sonuç olarak bazı sınırlı olumlu görüş bildiren raporların hisse senedi fiyatlarını yönlendirdiğini dolayısıyla yatırımcı kararlarını da etkilediğini tespit etmişstir.

Houghton (1983), çalışmasında denetim görüşlerindeki farklılığın henüz rapor oluşmadan, karar alma sürecinde ve hisse senedi fiyatlarında değişime sebep olup olmadığını incelemiştir. Araştırmada olumlu, sınırlı olumlu raporlar ve aynı zamanda raporsuz finansal tablolar değerlendirilmiştir. Sonuçta bu üç durumun hisse senedi fiyatlarında çok önemli bir yönlendirme yaratmadığını elde etmiştir.

Gul (1990) çalışmasında aynı anda sınırlı olumlu ve olumlu denetim görüşlerinin hisse senedi fiyatları üzerinde etkisi olup olmadığını araştırmıştır. Elde ettiği bulgulara göre, olumlu denetim görüşü hisse senedi fiyatları üzerinde etki yaratmazken; sınırlı olumlu denetim görüşünün hisse senedi fiyatlarında olumsuz yönde etki oluşturmuştur. 
Ameen ve diğerleri (1994) yaptıkları çalışmalarında; Amerika'da özellikle organize olmayan piyasalarda faaliyet gösteren işletmeler için olumsuz denetim görüşünün herhangi bir bilgi değerinin olup olmadığını araştırmışlardır. Sonuçlara göre analiz edilen; işletmelerin hisse senetleri fiyatlarında olumsuz denetim görüşünün açıklanması öncesinde olumsuz yönlü değişiklikler tespit edilmiştir.

Chen ve diğerleri (2000) Çin de gerçekleştirdikleri çalışmalarında; işletmelerin hisse senedi fiyatlarının olumlu ya da olumsuz denetim görüşleri karşısında yön değiştirip değiştirmediğini değerlendirmişlerdir. Sonuçlara göre olumsuz denetim görüşüne sahip işletmeler adına anormal negatif getiriler tespit edilmiştir.

Duréndez Gómez-Guillamón (2003) yaptıkları çalışmalarında; denetçi görüşü içeren denetim raporlarının hisse senedi yatıım şirketlerine dair yatırım ve kredi kuruluşlarının borç verme karar süreçlerine etkisini araştırmışlardır. Sonuçlar; denetçi görüşlerinin karar verici konumundakiler için oldukça önemli bir araç olduğunu ve yatırım ve kredi verme davranışlarını anlamlı olarak etkilediğini göstermektedir.

Lin ve diğerleri (2003) Çin'de yaptıkları çalışmalarında; yatırımcı ve kredi verme kuruluşlarının olumlu ve olumsuz denetim görüşleri verildiği takdirde karar alma süreçlerinde bir değişim yaşayıp yaşamadıklarını incelemişleridir. Sonuçta; olumsuz denetim görüşlerinin şirkete ilişkin yatırım ve borç verme kararlarını olumsuz şekilde etkilediği tespit edilmiştir.

Martinez, Martinez ve Benau (2004), İspanya da yaptıkları çalışmalarında; şartlı denetim görüşü ile hisse senedi fiyatları arasında herhangi bir etkileşim olup olmadığını araştırmışlardır. Sonuçlara göre, sınırlı olumlu denetim görüşünün bilgi değerine sahip olmadığı ve denetim görüşü ile hisse senedi fiyatı arasında bir ilişki olmadığı tespit edilmiştir.

Aygören ve Uyar (2007) çalışmalarında denetçi görüşlerinin hisse senedi getirilerine etkisini araştırmışlardır. Sonuçta; yatırımcıların anormal getiriler elde ettiği, olumlu ve sınırlı olumlu denetim görüşlerinin yatırımcılar üzerinde farklı bilgi değeri yarattığı elde edilmiştir.

O’Relly (2010), çalışmasında görüş bildirmekten kaçınılmış denetim raporlarının; yatırımcılar için değerli bir bilgi olup olmadığını araştırmayı amaçlamıştır. Sonuç olarak; bu bilginin, yatırım yapanlar için önemli niteliğe sahip olduğu ortaya çıkmıştır.

Kara (2015) yaptığı çalışmasında; denetim görüşlerinin hisse senedi getirilerinde herhangi bir etkiye sahip olup olmadığını araştırmıştır. Sonuçta iki değişken arasında pozitif yönlü bir ilişki varlı̆̆ 1 , olay öncesi ve sonrasında endeks kapsamındaki şirketlerin hisse senetlerinden anormal getirilerin elde edilebildiği tespit edilmiştir.

Literatür taraması neticesinde, denetim raporlarında yer alan denetçi görüşlerinin şirketlerin hisse senedi fiyatlarını kısa süreliğine de olsa etkilediğine dair bulgulara ulaşılmaktadır. Denetçilerin, şirketlerin finansal tablolarına ilişkin olumlu görüşlerinin, yatırımcıların kararlarını ve hisse senetlerinin pozitif yönlü hareket etmesini etkilediği görülmektedir (Chow ve Rice, 1982; Chen vd., 2000).

Firmalara özgü kalemlerin ve oranların (piyasa değeri, piyasa değeri/defter değeri, fiyat/kazanç oranı, firma büyüklüğü gibi), borsada işlem gören hisse senetlerinin değerini 
etkilediğini ve yatırımcıların bu söz konusu değişkenleri dikkate alarak özellikle "değer yatırımı" stratejisi ile normalüstü bir getiri elde etme imkânlarının olduğunu gösteren literatürde çok sayıda bulgu söz konusudur. Firmalara özgü bu faktörlerin meydana getirdiği etki küçük bile olsa, riskli kararlarda \%1'lik bir değişim bile yıllar içinde toplamda büyük kazançlar veya zararlar meydana getirebilmektedir. Anomali, kamusal bir olayı takip eden süreçte hisse senedi getirilerinde ortaya çıkabilecek anormal getirilerdir (Daniel vd., 1998, s. 1839). Bu çalışma; bağımsız denetçi görüşlerinin de yer aldığı bağımsız denetim raporlarının kamuya açıklanmasının ardından şirketlerin hisse senedi fiyatlarındaki anormal fiyat hareketlerinin varlığını ve bahsi geçen firmalara özgü anomalilere bir yenisinin daha eklenebilip eklenemeyeceğini araştırmaktadır.

\section{ANALIZ VE BULGULAR}

$\mathrm{Bu}$ çalışma; bağımsız denetçi görüşlerinin de yer aldığı bağımsız denetim raporlarının kamuya açıklanması sonrasında şirketlerin hisse senedi fiyatlarındaki anormal fiyat hareketlerinin var olup olmadığını ve bu kapsamda firmalara özgü anomalilere bir yenisinin daha eklenebilip eklenemeyeceğini araştırmayı amaçlamaktadır.

$\mathrm{Bu}$ amaç doğrultusunda; BDS 705'den hareketle olumlu denetçi görüşleri dişındaki tüm denetçi görüşleri olumsuz denetçi görüşü olarak nitelendirilmiş ve sınırlı olumlu, olumsuz ve görüş bildirilmekten kaçınılan denetim raporlarına sahip şirketlerin 2019 ve 2020 yılına ait altı aylık süreler içerisindeki hisse senedi getirileri hesaplanarak portföy oluşturulmuş, BIST TUM ile BIST 100 endeksinin getirileri ile karşılaştırılmış ve anormal bir getiri (endeksin üzerinde) elde edilip edilmediği tespit edilmeye çalışılmıştır.

Çalışmanın yanıt aradığı sorular şunlardır:

- $\quad$ Olumsuz denetçi görüşüne sahip şirketlerin hisse senetlerinden oluşturulan portföyün getirisi BIST TUM ve BIST 100 endeksi getirisinin üzerinde midir?

- $\quad$ BİST, analizi gerçekleştirilen dönemler için yarı güçlü formda etkin midir?

- $\quad$ Denetçi görüşleri yatırım kararları açısından dikkate alınması gereken bir faktör müdür?

- $\quad$ Finansal piyasalarda görülen firmalara özgü normalden sapmalar olarak ifade edilen kesitsel anomalilere «Denetçi Görüşü Anomalisi / Bă̆ımsız Denetim Görüşü Anomalisi» isimli yeni bir anomalinin dâhil edilmesi mümkün müdür?

Çalışmanın veri seti; BISST, Kamuyu Aydınlatma Platformu (KAP) ve FINNET Finansal Veri Sağlayıcısı' ndan elde edilmiştir. Hisse senetleri BİST' de işlem gören tüm şirketlerin 2019/6, 2019/12 ve 2020/6 dönemlerindeki denetimden geçmiş finansal tabloları için bildirilen denetçi görüşleri KAP'tan elde edilmiştir. KAP' tan edinilen denetçi görüşleri tasnif edilerek Olumlu Denetim Görüşü' nde bulunulan şirketlerin hisse senetlerinden ve Olumsuz Denetim Görüşü'nde bulunulan şirketlerin hisse senetlerinden iki ayrı portföy oluşturularak bir sonraki denetim görüşüne kadar geçen süre sonundaki (6 ay) getirileri hesaplanmıştır. Şirketlerin analizi gerçekleştirilen dönemlere ilişkin hisse senedi kapanış fiyatları BİST'in resmî web sayfasından elde edilmiştir.

Bağımsız denetçi görüşüne ulaşılamayan ve diğer şirketlerden farklı dönemlerde finansal raporlarını yayımlayan şirketler analizin kapsamına dâhil edilmemiştir. Bu husus 
çalışmanın kısıtını oluşturmaktadır. Tablo 2'de çalışmanın analizinde kullanılacak olan, söz konusu dönemler içerisinde verilerine eksiksiz biçimde ulaşılan şirketlerin bağımsız denetim raporlarında yer alan bağımsız denetçi görüşleri yer almaktadır.

Tablo 2. Bağımsız Denetçi Görüşleri (2019/6-2020/6)

\begin{tabular}{|c|c|c|c|c|c|}
\hline & Olumlu & Olumsuz & Görüş Bildirmekten Kaçınma & Sınırlı Olumlu & \multirow{2}{*}{ TOPLAM } \\
\hline & OLUMLU & \multicolumn{3}{|c|}{ OLUMSUZ } & 364 \\
\hline $\mathbf{2 0 1 9 / 6}$ & 316 & 1 & 5 & 42 & 37 \\
\hline $\mathbf{2 0 1 9 / 1 2}$ & 314 & 1 & 5 & 53 & $\mathbf{3 7 3}$ \\
\hline $\mathbf{2 0 2 0 / 6}$ & 314 & 2 & 4 & 57 \\
\hline
\end{tabular}

Tablo 2'de yer aldığg üzere, 2019 yılının ilk altı ayını içeren denetim raporlarında incelenen toplam 364 şirketin 316'sına denetçiler olumlu görüş bildirmiş, 48'ine ise olumsuz olarak gruplandırılan görüş bildirmişlerdir. 2019'un dönem sonu bağımsız denetim raporlarına bakıldığında, 377 şirketten 63 'ünün olumsuz denetçi görüşüne sahip olduğu görülmektedir. $2020 / 6$ 'da ise, toplam 59 şirkete denetçilerin çeşitli sebeplerle olumlu dişında görüş bildirdiği tespit edilmiştir. Bu doğrultuda olumsuz denetçi görüşüne sahip şirketlerin hisse senetlerinden bir sonraki bağımsız denetçi görüşüne kadar geçen süreliğine (6 ay) portföy oluşturularak, aynı dönemleri içerek biçimde BIST 100 ve BIST Tüm endeksinin getirileri ile karşılaştırılmıştır. Tablo 3'de analizi gerçekleştirilen şirketlerin hisse senetlerinden oluşturulan portföylerin süreleri yer almaktadır.

Tablo 3. Portföy Tarihleri

\begin{tabular}{|l|l|l|l|}
\hline & $\begin{array}{l}\text { Bağımsız Denetim } \\
\text { Raporu Dönemi }\end{array}$ & Portföy Tarihleri & Portföy Süresi \\
\hline $\mathbf{1}$ & $2019 / 6$ & $01.10 .2019-01.04 .2020$ & $\begin{array}{l}\text { Bir Sonraki Bağımsız Denetçi } \\
\text { Görüşünün Yer Aldığ } \text { Denetim } \\
\text { Raporunun İlânı (6 ay) }\end{array}$ \\
\hline $\mathbf{2}$ & $2019 / 12$ & $01.04 .2020-01.10 .2020$ & $\begin{array}{l}\text { Bir Sonraki Bağımsız Denetçi } \\
\text { Görüşünün Yer Aldığ Denetim } \\
\text { Raporunun İlânı (6 ay) }\end{array}$ \\
\hline $\mathbf{3}$ & $2020 / 6$ & $01.10 .2020-01.04 .2021$ & $\begin{array}{l}\text { Bir Sonraki Bağımsı Denetçi } \\
\text { Görüşünün Yer Aldığ Denetim } \\
\text { Raporunun İlânı (6 ay) }\end{array}$ \\
\hline
\end{tabular}

2019/6 dönemine ilişkin olarak olumsuz denetçi görüşü verilmiş 48 şirketin hisse senetlerinden Tablo 3'de belirtilen süreleri kapsayacak biçimde portföy oluşturulmuş ve aynı dönemi kapsayan BIST 100 ve BIST Tüm endeksi getirileri ile karşılaştırılmıştır. Tablo 4'te bahsi geçen analizin bulguları yer almaktadır.

Tablo 4. 2019/6 Dönemine İlişkin Bulgular (01.10.2019-01.04.2020)

\begin{tabular}{|c|c|c|c|}
\hline $\begin{array}{c}\text { Olumsuz Denetçi Görüşüne Sahip } \\
\text { Şirketlerin (48 adet) Hisse Senetlerinden } \\
\text { Oluşturulan Portföyün Getirisi }\end{array}$ & $\begin{array}{l}\text { Olumsuz Denetçi Görüşüne } \\
\text { Sahip Şirketlerin Hisse } \\
\text { Senetlerinin Ortalama Getirisi }\end{array}$ & $\begin{array}{l}\text { BIST TUM } \\
\text { Endeksi } \\
\text { Getirisi }\end{array}$ & $\begin{array}{l}\text { BIST } 100 \\
\text { Endeksi } \\
\text { Getirisi }\end{array}$ \\
\hline$\% 26.46$ & $\% 26.29$ & (\% 10.97) & (\% 14.24) \\
\hline
\end{tabular}

Olumsuz denetçi görüşlü 48 şirketin hisse senetlerinden oluşan portföyün altı aylık sürede \%29.46 getiri elde ettiği, getirilerin ortalamasına bakıldığında tüm şirketlerin bu getiri ortalamasına ulaştığı görülmektedir. Bunun yanı sıra, aynı dönem içerisinde BIST Tüm 
endeksinin \%10'un üzerinde, BIST 100 endeksinin ise \%14'ün üzerinde değer kaybettiği tespit edilmiştir. Tablo 5'de analizi gerçekleştirilen bir sonraki döneme ait (2019/12) bulgular yer almaktadır.

Tablo 5. 2019/12 Dönemine İlişkin Bulgular (01.04.2020-01.10.2020)

\begin{tabular}{|c|c|c|c|}
\hline $\begin{array}{c}\text { Olumsuz Denetçi Görüşüne Sahip } \\
\text { Şirketlerin (63 adet) Hisse Senetlerinden } \\
\text { Oluşturulan Portföyün Getirisi }\end{array}$ & $\begin{array}{c}\text { Olumsuz Denetçi Görüşüne } \\
\text { Sahip Şirketlerin Hisse } \\
\text { Senetlerinin Ortalama Getirisi }\end{array}$ & $\begin{array}{c}\text { BIST TUM } \\
\text { Endeksi } \\
\text { Getirisi }\end{array}$ & $\begin{array}{c}\text { BIST 100 } \\
\text { Endeksi } \\
\text { Getirisi }\end{array}$ \\
\hline $\mathbf{\% ~ 1 2 5}$ & $\mathbf{\% 2 1 0 . 7 7}$ & $\mathbf{\% ~ 3 8 . 8 3}$ & $\mathbf{\% ~ 2 8 . 3 6}$ \\
\hline
\end{tabular}

Tablo 5’de yer bulgular incelendiğinde, olumsuz denetçi görüşlü 63 şirketin hisse senetlerinin altı aylık süre içerisinde ortalama \%210.77 değer kazandığ değerlemenin portföyün \%125 getirisi ile neticelendiği görülmektedir. Bununla birlikte, incelenen her iki endeksinde getirisinin pozitif olduğu ancak olumsuz denetçi görüşüne sahip şirketlerin hisse senetlerinden oluşan portföyün getirisinin oldukça altında kaldığı tespit edilmiştir. Tablo 6'da analizi gerçekleştirilen son dönem olan 2020/6'ya ait bulgular yer almaktadir.

Tablo 6. 2020/6 Dönemine İlişkin Bulgular (01.10.2020-01.04.2021)

\begin{tabular}{|c|c|c|c|}
\hline Olumsuz Denetçi Görüşüne Sahip & Olumsuz Denetçi Görüşüne & BIST TUM & BIST 100 \\
Şirketlerin (59 adet) Hisse Senetlerinden & Sahip Şirketlerin Hisse & Endeksi & Endeksi \\
Oluşturulan Portföyün Getirisi & Senetlerinin Ortalama Getirisi & Getirisi & Getirisi \\
\hline \% 71.65 & $\mathbf{\% ~ 5 4 . 6 8}$ & $\mathbf{\% ~ 2 8 . 2 2}$ & $\mathbf{\% ~ 2 4 . 7 5}$ \\
\hline
\end{tabular}

Tablo 6'da yer alan bulguların Tablo 5'deki bulgularla büyük oranda benzeştiği görülmektedir. Söz konusu dönemdeki olumsuz denetçi görüşlü şirketlerin hisse senetlerinden meydana gelen portföyün getirisinin BIST Tüm ve BIST 100 endeksi getirilerinden neredeyse 3 katı oranında fazla olduğu sonucuna ulaşılmıştır. Tablo 7'de getirilere ilişkin bulgulara ek olarak, söz konusu dönemlerde hisse senedi artan ve azalan olumsuz denetçi görüşüne sahip şirketlerin sayısı yer almaktadır.

Tablo 7. Hisse Senedi Fiyatı Artan ve Azalan Şirket Sayısı

\begin{tabular}{|c|c|c|c|}
\hline & $\begin{array}{c}\text { Hisse Senedi Fiyatı } \\
\text { Artan }\end{array}$ & $\begin{array}{c}\text { Hisse Senedi Fiyatı } \\
\text { Azalan }\end{array}$ & TOPLAM \\
\hline $\begin{array}{c}\text { Olumsuz Denetçi Görüşüne Sahip Şirketler } \\
\text { (2019/6) }\end{array}$ & $33(\% 68.75)$ & $15(\% 31.25)$ & $\mathbf{4 8}$ \\
\hline $\begin{array}{c}\text { Olumsuz Denetçi Görüşüne Sahip Şirketler } \\
\text { (2019/12) }\end{array}$ & $60(\% 95.24)$ & $3(\% 4.76)$ & $\mathbf{6 3}$ \\
\hline $\begin{array}{c}\text { Olumsuz Denetçi Görüşüne Sahip Şirketler } \\
\text { (2020/6) }\end{array}$ & $50(\% 84.75)$ & $9(\% 15.25)$ & $\mathbf{5 9}$ \\
\hline
\end{tabular}

Tablo 7'de yer alan bulgular incelendiğinde, analizi gerçekleştirilen tüm portföy dönemlerinde olumsuz denetçi görüşüne sahip şirketlerin hisse senetlerinin yarısından fazlasının altı aylık sürede değer kazandığı görülmektedir. 2019/12 dönemine 63 şirketin tamamına yakınının (\%95.24) hisse senedinin değer kazandığı, dolayısıyla yatırımcıların bu şirketlerin hisse senetlerini tercih ettiklerinde büyük oranda değer kazanacak olan bir şirkete yatırım yaptığı sonucuna ulaşılmaktadır. 
Elde edilen bulgulara standart finans ve davranışsal finans perspektifinden bakıldığında; etkin bir piyasada değer yatırımına benzer biçimde (düşük PD/DD oranına ya da düşük $\mathrm{F} / \mathrm{K}$ oranı sahip şirketlerin hisse senetlerinden portföy oluşturarak normal üstü (endeksin üzerinde) getiri elde edilmeye çalışılması) yatırım stratejisi geliştirilerek endeksin üzerinde bir getiri elde edilmesi mümkün değildir. Ancak analizi gerçekleştirilen tüm dönemlerde, denetçi görüşü olumsuz olmasına rağmen bahsi geçen şirketlerin hisse senetlerinden oluşturulan portföyün endeksin üzerinde getiri elde ettiği görülmektedir. $\mathrm{Bu}$ durum; yatırımcıların olumsuz denetçi görüşüne sahip şirketlerin hisse senetlerine yatırım yaparak normal üstü (endeksin üzerinde) bir getiri elde edebilecekleri anlamının yanı sıra, BİST'in analizi gerçekleştirilen dönemler için yarı güçlü formda etkin olmadığı anlamını da taşımaktadır.

\section{SONUÇ}

Bağımsız denetimden geçen şirketlerin denetim raporlarında finansal bilgiler kadar finansal olmayan bilgilerin de iktisadi aktörler tarafından dikkate alındığı/alınması gerektiği bilinmektedir. Bağımsız denetçilerin şirketlerin finansal tablolarında yer alan kalemlerin standartların gerektirdiği biçimde sahip olmaları gereken şartları sağlayıp sağlamadığından hareketle belirtmiş oldukları görüşleri, son yıllarda bilgi kullanıcılarının önem verdiği başlıkların başında gelmektedir.

Bağımsız denetçi görüşlerini dikkate alarak gerçekleştirilen bu çalışmadan elde edilen sonuçları ve araştırma sorularına verdiği yanıtları şu şekilde sıralamak mümkündür:

Bağımsız denetçi görüşleri, yatırımcıların yatırım kararları öncesi dikkate almaları gereken önemli faktördür.

Olumsuz denetçi görüşlerine sahip şirketlerin hisse senetlerinden oluşturulan portföyler 6 aylık süreler içerisinde incelenen tüm dönemlerde BIST 100 endeksinin üzerinde getiri elde etmiştir. Şirketler açısından oldukça olumsuz bir durumun, hisse senedi fiyatlarına ters yönlü yansıması; davranışsal finansın mikro kısmının konusu içerisine giren bireylerin rasyonel olmadığ 1 ve çeşitli duygusal ve bilişsel yanlılıklarla karar aldıkları iddiasının doğruluğunu güçlendirmektedir. Bu çalışmada da kısmen ortaya çıkan bu yanlılıkların meydana getirdiği hisse senedi piyasalarındaki normalden sapmaların (anomalilerin) irrasyonel açıklamalara ihtiyaç duyduğu görülmektedir. Tam da bu noktada, anomalileri izah etmek için akıl dışı açıklamalar gerektiği görüşünü hatırlamakta fayda vardır.

$>\quad$ Bir piyasanın yarı güçlü formda etkin olabilmesi için hisse senedi fiyatlarının geçmiş dönem verilerinden, şirketlerin bağımsız denetim raporlarında yer alan bilgilerden ve kamuya açıklanan bildirimlerden yola çıkarak normal üstü getiri elde etmenin mümkün olmaması gerekmektedir. Standart finansın temel varsayımlarından biri olan piyasaların etkin olduğu görüşünün tersi yönünde bulguların elde edildiği bu çalışma; BİST' in ele alınan dönemlerde Etkin Piyasa Hipotezi' ndeki bilgi etkinliği formlarından yarı güçlü formda etkin olmadığını ortaya koymaktadır.

Davranışsal finans literatüründe yer alan ve geçerliliği gelişmiş/gelişmekte olan piyasalarda defalarca kez kanıtlanmış olan kesitsel anomalilerin ortaya konduğu çalışmalarda; anomali olarak kabul edilme şartının, seçilen değişkene bağlı olarak oluşturulan portföyün 
borsa endeksi üzerinde bir getiri meydana getirmesi olduğu görülmektedir. Bu çalışmada söz konusu temel şartın sağlandığı görülmektedir. Ancak literatüre "bağımsız denetçi anomalisi" ya da "denetçi görüşü anomalisi" olarak dâhil edilebilmesi için çeşitli piyasalarda tekrarlayan biçimlerde ortaya çıktığının tespit edilmesi gerekmektedir. $\mathrm{Bu}$ açıdan bakıldığında; literatürdeki bulgulardan ve çalışmanın sonuçlarından hareketle, söz konusu faktörün bir anomali boyutuna gelecek potansiyele sahip olduğu düşünülmektedir.

Bağımsız denetçi görüşlerinin de yer aldığı bağımsız denetim raporlarının kamuya açıklanması sonrasında şirketlerin hisse senedi fiyatlarında anormal fiyat hareketlerinin var olup olmadığını ve özellikle olumsuz denetçi görüşlerine sahip şirketlerin hisse senedi fiyatlarının bu istenmeyen durumdan ne yönde etkilendiklerini araştıran çalışmaların alanyazında yeterince ortaya çıkarılmadığı görülmektedir. Bu çalışma, söz konusu eksikliği gidermeye yönelik özgün değere sahip bulguları olan bir çalışma olarak nitelendirilme iddiasındadır. Bunun yanı sıra çalışma; varmış olduğu sonuçların yanında, benzer içerikli çalışmalara çeşitli öneriler getirmektedir.

Bağımsız denetim raporlarından hareketle, bağımsız denetçi görüşü olarak özellikle olumsuz görüş bildirilmesinin nedenlerine bakılıp, söz konusu faktörler özelinde benzer içerikli çalışmalar yapılabilir.

$\mathrm{Bu}$ alandaki diğer pek çok çalışmada olduğu gibi, analizin kapsamı ve yöntemi değiştirilerek benzer veya farklı bulguların elde edilip edilmediği araştırılabilir.

Yatırımcıların bağımsız denetçiler olumsuz görüş bildirmelerine rağmen o şirketlerin hisse senetlerine yatırım yaparak normal üstü getiri elde etmeleri hususu, fiyat anomalilerinden olan aşırı tepki anomalisi ile ilişkili olabilir mi? sorusuna yanıt aranabilir.

Bireysel ve sofistike yatırımcılara denetçi görüşlerine bakarak yatırım kararı alıp almadıkları sorularak, kesitsel anomali potansiyeli taşıyan bu durumun davranışsal finansın mikro kısmı ile ilişkisi ortaya konabilir.

Davranışsal finansın makro çalışmaları, standart finansın temel hipotezlerinden biri olan piyasa etkinliğine karşı, piyasaların etkin değil yenilmesi zor piyasalar olarak ifade edilmesi gerektiğini ileri sürmektedir. Bu görüşü destekleyen bulgular, hisse senedi piyasalarında normalden sapmaların (anomalilerin) var olduğunu ve bunların bir kısmının zamana dayalı olmamakla birlikte firmalara özgü olduğunu göstermektedir. Kesitsel anomaliler olarak adlandırılan ve etkin bir piyasada gözlemlenmesi mümkün olmayan bu anormal olgulara, şirketlerin bağımsız denetçi görüşlerindeki farklılıkların da eklenebileceği benzeri çalışmalarda tekrarlanan düzeyde bulgulara ulaşılmasıyla görülebilecektir.

\section{KAYNAKLAR}

Acar, Merve - Temiz, Hüseyin (2019), "Denetçi Görüşlerinin Pay Senedi Getirileri Üzerindeki Etkisi”, Muhasebe ve Denetime Bakış, (58), ss. 173-194.

Ameen, Elsie C. - Chan, Kam - Guffey, Daryl M. (1994), “Information content Of Qualified Audit Opinions For Over-The-Counter Firms", Journal of Business Finance \& Accounting, 21(7), pp. 997-1011. 
Arens, Alvin A. - Elder, Randal J. - Beasley, Mark S.- Hogan, Chris E. (2012), Auditing And Assurance Services: An Integrated Approach: Boston: Prentice Hall.

Aygören, Hakan - Uyar, Süleyman (2007), “İstanbul Menkul Kıymetler Borsası'nda (İMKB) denetim görüşlerinin hisse senedi getirileri üzerindeki etkisi”. İMKB Dergisi, 9(36), ss. $33-51$.

Barak, Osman - Demireli, Erhan (2008), “iMKB' de Aşırı Reaksiyon Anomalisi Ve Davranışsal Finans Modelleri Kapsamında Değerlendirilmesi”, Gazi Üniversitesi İktisadi ve İdari Bilimler Fakültesi Dergisi, Cilt 10, Vol.1, ss. 207-229

Barberis, Nicholas - Shleifer, Andrei - Vishny, Robert. (1998), “A Model of Investor Sentiment”, Journal of Financial Economics, Vol: 49, pp. 307-343.

Bessell, Max - Anandarajan, Asokan - Umar, Ahson (2003), "Information Content, Audit Reports And Goingconcern: An Australian Study”, Accounting \& Finance, 43(3), pp. 261-282.

Chen, Charles J. - Su, Xijia - Zhao, Ronald (2000), “An Emerging Market’s Reaction To Initial Modified Audit Opinions: Evidence From The Shanghai Stock Exchange”, Contemporary Accounting Research, 17(3), pp. 429-455.

Coşkun, Sevda - Karataş, Yasemin - Güleç, Tuna Can (2016), "BIST 100 endeksinde dönemsel anomalilerin test edilmesi”, https://d1wqtxts1xzle7.cloudfront.net/54023242/BIST_100de_DONEMSEL_ANOM ALI_TESTI_14.03.2016.pdf (Erişim Tarihi: 05.04.2021)

Duréndez Gómez-Guillamón, A. (2003), “The Usefulness Of The Audit Report in Investment And Financing Decisions”, Managerial Auditing Journal, 18(6/7), pp.549-559.

Erdoğan, Muammer - Elmas, Bekir (2010), "Hisse Senedi Piyasalarında Görülen Anomaliler ve Bireysel Yatırımcı Üzerine Bir Araştırma”, Atatürk Üniversitesi Sosyal Bilimler Enstitüsü Dergisi, 14 (2), ss.1-22

Firth, Michael (1978), “Qualified Audit Reports: Their Impact On Investment Decisions”, Accounting Review, pp. 642-650.

Gul, Ferdinand A. (1990), “Qualified Audit Reports, Field Dependence Cognitive Style, And Their Effects On Decision Making”, Accounting \& Finance, 30(2), pp.15-27.

Güngör, Bener. (2003), "Finans Literatüründe Anomali Kavramı Ve Etkin Piyasalar Hipotezi”, Atatürk Üniversitesi İktisadi ve İdari Bilimler Dergisi, 17(1-2), ss. 109-133.

Güredin, Ersin (2014), Denetim ve Güvence Hizmetleri, 14. Bask1, Türkmen Kitabevi, İstanbul.

Houghton, Keith A. (1983), “Audit Reports: Their İmpact On The Loan Decision Process And Outcome: An Experiment”, Accounting and Business Research, 14(53), pp.15-20. 
Kara, Suat (2015), “Denetim Görüşlerinin Hisse Senedi Anormal Getirileri Üzerine Etkisinin 2009-2014 Yılları Bazında Ölçümlenmesi”. Muhasebe ve Vergi Uygulamaları Dergisi (Muvu)/Journal of Accounting \& Taxation Studies (Jats), 8(2).

Lin, Z. Jun - Tang, Qingliang - Xiao, Jason (2003), “An Experimental Study Of Users' Responses To Qualified Audit Reports in China”, Journal of International Accounting, Auditing And Taxation, 12(1), pp.1-22.

Martínez, Maria Consuelo Pucheta - Martínez, Antonio Vico - Benau, Maria Antonia Garcia (2004), "Reactions of the Spanish Capital Market To Qualified Audit Reports", European Accounting Review, 13(4), pp. 689-711.

O’Reilly, Dennis M. (2010), “Do Investors Perceive The Going-Concern Opinion As Useful For Pricing Stocks?”, Managerial Auditing Journal, 25(1), pp. 4-16.

Sekizsu, Bilge - Ertaş, Fatih Coşkun. (2018), “Şirketlerin Bağımsız Denetim Raporlarının Analizi: BİST’de Bir Araştırma”, Muhasebe ve Finansman Dergisi, (80), ss. 43-64.

Şahin, Özkan (2015), BİST’ teki Endekslerin Volatilitelerinin Karşılaştırmalı Analizi: BİST Kurumsal Yönetim, BİST 100, BİST 50 ve BİST 30 Endeksleri Üzerinde Bir Uygulama, Doktora Tezi, Düzce Üniversitesi, Düzce.

Şahin, Özkan (2016), “Güniçi Fiyat Anomalisi’nin ARCH Ailesi Modelleri İle Test Edilmesi: Borsa İstanbul 100 ve Kurumsal Yönetim Endeksi Üzerine Bir Uygulama”, Balıkesir Üniversitesi Sosyal Bilimler Enstitüsü Dergisi, 19(36), ss. 329-360.

Thaler, Richard. H. (1988), “Anomalies: The Ultimatum Game”, The Journal of Economic Perspectives, 2(4), pp. 195-206. 
